\title{
19. A PRELIMINARY REPORT OF EARLY CRETACEOUS DINOCYST FLORAS FROM SITE 765, ARGO ABYSSAL PLAIN, NORTHWEST AUSTRALIA ${ }^{1}$
}

\author{
R. Helby ${ }^{2}$ and A. McMinn ${ }^{3,4}$
}

\begin{abstract}
Results of a preliminary study of Early Cretaceous dinocyst assemblages from Site 765 on the Argo Abyssal Plain, off northwestern Australia, are presented. The palynological sequence is interpreted in terms of Australian zones and is, in descending order, the late Aptian Diconodinium davidii Zone (Cores 123-765C-33R to -39R), the middle to early Aptian Odontochitina operculata Zone (Cores 123-765C-40R to -49R), the Barremian Muderongia australis Zone (Cores 123-765C-50R to -54R), and the Berriasian lower Batioladinium reticulatum Zone (Core 123-765C-59R). The dating of the sequence as late Aptian to Berriasian on the basis of dinocysts is supported, in part, by data concerning associated foraminiferal, radiolarian, and calcareous nannofossil suites.
\end{abstract}

\section{INTRODUCTION}

Well-preserved, variably diverse, Early Cretaceous dinoflagellate cyst (dinocyst) assemblages were recovered from Site 765 of Leg 123. This site was located on marine magnetic anomaly M26 on the Argo Abyssal Plain, approximately $400 \mathrm{~km}$ north of Port Hedland, at $15^{\circ} 58.541^{\prime} \mathrm{S}, 117^{\circ} 34.495^{\prime} \mathrm{E}$ (Fig. 1), in a water depth of $5728.5 \mathrm{~m}$. The sedimentary sequence at Site 765 is presented in Figure 2. Although Neogene dinocysts were recorded at higher levels (McMinn, this volume), attempts to recover dinocysts from intervening samples were unsuccessful. The dinocyst associations have been interpreted in terms of the zonation outlined by Helby et al. (1987).

Wiseman and Williams (1974), in the only published report of dinocysts from the Argo Abyssal Plain, recorded Barremian and Aptian assemblages at Site 261, referable to the interval between the lower Muderongia australis and lower Odontochitina operculata zones. Helby et al. (1987) summarized relevant Australian dinoflagellate studies prior to 1987. Backhouse (1988) published a major study of Late Jurassic to Early Cretaceous palynology of the Perth Basin, Western Australia, while Ingram and Morgan (1988) reviewed the development and status of Mesozoic palynostratigraphy of the Australian Northwest Shelf, and Islam (1988) discussed aspects of a Rhaetian to Barremian sequence in the Beagle and Dampier sub-basins, off Western Australia.

\section{MATERIALS AND METHODS}

Twenty-six samples were selected for study on the basis of relative palynomorph productivity and position, although some specimens from unreported samples are illustrated. Location details are given in Figure 2. The samples were processed by conventional techniques on board the Resolution. Preliminary interpretation of the samples was undertaken during the cruise by McMinn. Quantitative data are based on rapid counts of 200 specimens (or lesser available number; by McMinn). Helby recorded assemblage data. The strew mounts are deposited in the

\footnotetext{
${ }^{1}$ Gradstein, F. M., Ludden, J. N., et al., 1992. Proc. ODP, Sci. Results, 123: College Station, TX (Ocean Drilling Program).

2 356A Burns Bay Rd, Lane Cove, New South Wales 2066, Australia

${ }^{3}$ New South Wales Geological Survey, Bdg. B11a, University of New South Wales, Kensington, New South Wales 2033, Australia.

${ }^{4}$ Now at Institute of Antarctic and Southern Ocean Studies, University of Tasmania, G.P.O. Box 252C, Hobart, Tasmania 7001, Australia.
}

collections of the Geological Survey of New South Wales. Single-grain mounts have been retained (by Helby) pending further study.

\section{BIOSTRATIGRAPHY}

\section{Diconodinium davidii Zone}

Samples from Cores 123-765C-33R-1 to -39R-CC yielded extremely low to low numbers of palynomorphs. In Core 123 $765 \mathrm{C}-34 \mathrm{R}$, spores and pollen dominated the palynomorph suites, while microplankton dominated Cores $123-765 \mathrm{C}-33 \mathrm{R},-765 \mathrm{C}$ $35 \mathrm{R}$, and $-765 \mathrm{C}-39 \mathrm{R}$. Dinocyst diversity was variable and ranged from 9 to 48 species (Table 1). Samples were characterized by the common to abundant occurrence of Diconodinium davidii, with relatively common Dingodinium cerviculum and Rhombodella paucispina. Significant accessory species included Ascodinium sp. A, which occurs throughout and commonly constitutes a distinctive lower acme subzone of the $D$. davidii Zone in sequences elsewhere on the Australian Northwest Shelf. Canninginopsis intermedia has not been recorded previously at this level. Spiniferites content ranged from $2.5 \%$ to $4.5 \%$. An extremely meager dinocyst association in Core-123-765C-39R-CC contained several specimens of Diconodinium davidii and more numerous Ascodinium sp. A. In view of the extremely low palynomorph recovery, the assignment to the $D$. davidii Zone was tentative. Jurassic reworking was evident in samples from Cores 123-765C-37R and -39R.

\section{Odontochitina operculata Zone}

Samples from Cores $123-765 C-40 R-4$ to $-49 \mathrm{R}-\mathrm{CC}$ yielded low-to-moderate numbers of palynomorphs, dominated by microplankton (up to $99 \%$ ). Diversity of the dinocyst suites was variable (18-73 species). Samples were characterized by the relatively consistent occurrence of the eponymous species and the apparent absence of Ascodinium sp. A, Diconodinium davidii, and Pseudoceratium turneri. Muderongia macwhaei formed a distinctive subzone in the lower part of the interval, similar to those from the Carnarvon Basin. A Batiacasphaera subtilis plexus is intermittently dominant, while a Leptodinium acme occurred in the middle-to-lower part of the zone. Epitricysta vinckensis and Herendeenia postprojecta occurred in the lower part of the zone. Late Jurassic reworking was prominent in Cores $123-765 \mathrm{C}-45 \mathrm{R}$ and $-49 R$.

The Ovoidinium cinctum Zone (Helby et al., 1987) was not sampled. 


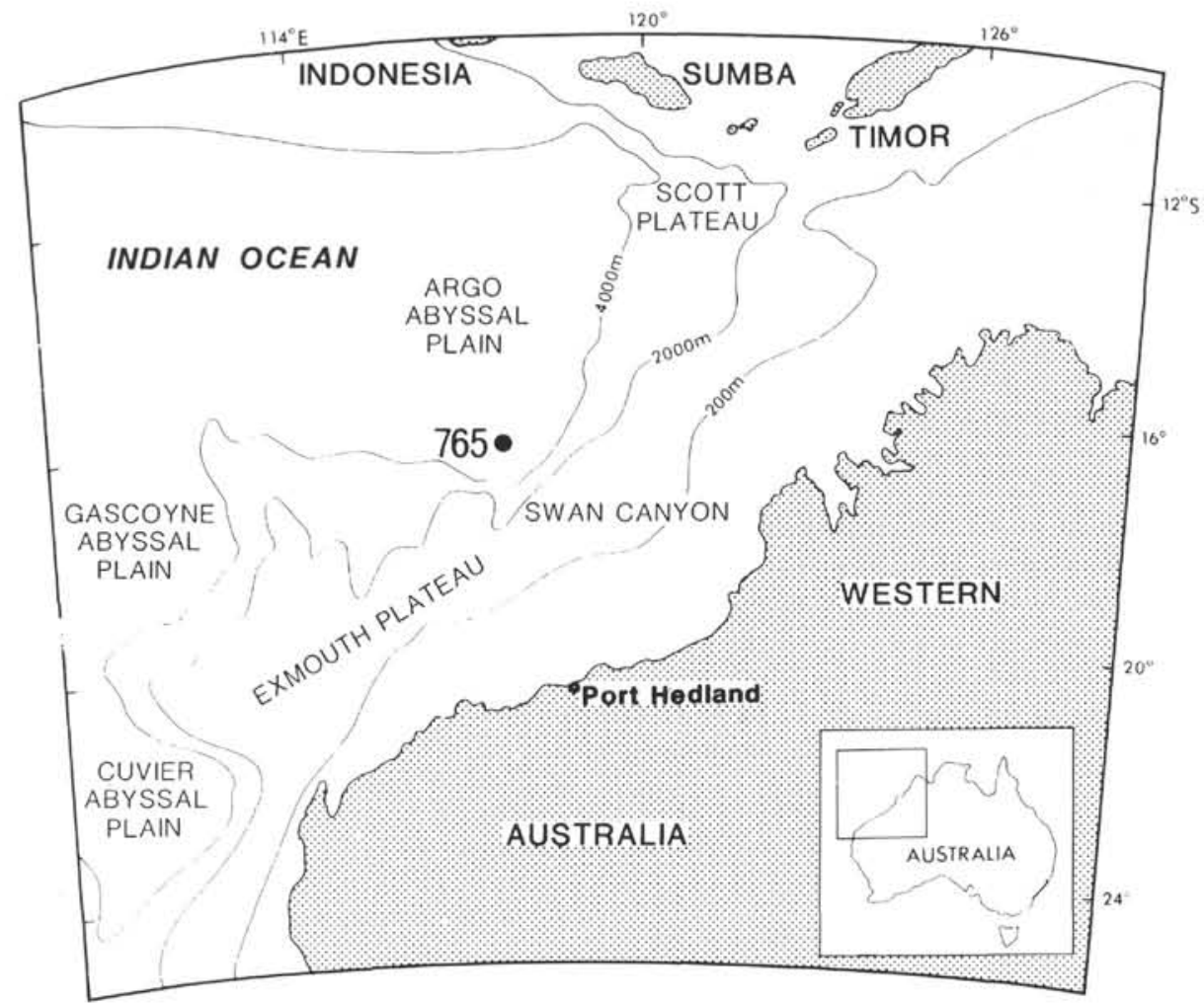

Figure 1. Location of Site 765.

\section{Muderongia australis Zone}

Samples from Cores 123-765C-50R-CC to -54R-CC yielded low-to-moderate palynomorph numbers. The palynomorph suites were completely dominated by relatively diverse microplankton associations (Table 1). The dinocyst assemblages were characterized by the occurrence of the eponymous species, with relatively consistent Belodinium dysculum, Circulodinium deflandrei, Cribroperidinium aparsium, Dingodinium cerviculum, Dissiliodinium sp. A, Herendeenia postprojecta, and Impagidinium phlyctaena. A Batiacasphaera imperfecta plexus acme and a Cribroperidinium(?) sp. cf. C. asarotum acme occurred in the upper part of the zone, while Dissiliodinium sp. A was abundant in the middle part of the zone. The occurrence of Phoberocysta neocomica in Core $123-765 \mathrm{C}-54 \mathrm{R}$ indicated that the associations are at least as old as the lower part of the zone. However, the apparent absence of twin-horned muderongoids, Gardodinium lowii and Senoniasphaera tabulata, suggested that these lower samples were not as old as the Hauterivian Muderongia testudinaria Zone. Jurassic reworking was noted in residues from Core 123-765C-54R. Core 123-765C-58R-2 yielded an extremely meager, almost monospecific, palynomorph residue of Kaiwaradinium scrutillinum, suggesting that it is no older than mid-Valanginian.

\section{Lower Batioladinium reticulatum Zone}

Samples from Cores 123-765C-59R-4 and -59R-5 yielded meager palynomorph residues. High-diversity microplankton suites dominated the residues (Table 1). The dinocyst associations were assigned to the lower zonule of the $B$. reticulatum Zone on the basis of the occurrence of the eponymous species with Dissimulidinium lobispinosum. Significant accessory species included Aldorfia(?) sp. A, Egmontodinium torynum, and Kleithriasphaeridium fasciatum. The occurrence of Wanaea species is evidence of reworking of Kimmeridgian to Callovian sediments, while the occurrence of Dingodinium cerviculum and Gardodinium attenuatum indicated downhole contamination of the samples.

\section{DISCUSSION}

Summary details are presented in Table 1. Dating of the dinoflagellate zones (adapted from Helby et al., 1987) is outlined together with data from calcareous nannofossil, radiolarian, and foraminiferal studies. The distribution of selected taxa in the samples is presented in Table 2. The distal position of Site 765 in relation to the Early Cretaceous basins of northwestern Australia provides an opportunity for testing quantitative variations in the zones.

The late Aptian Diconodinium davidii Zone occurred in lithologic Unit IV (von Rad et al., 1989, Fig. 9), which was predominantly claystone with turbiditic carbonates, nannofossil chalk, and zeolitic claystone; the samples were taken from medium to dark gray claystone beds. The palynomorph suites were characterized by variable ratios of microplankton to spores and pollen (1:5 to $4: 1$ ). Reworking was evident throughout this interval. In the Timor Sea region, the major part of the Aptian is supercondensed, sedimentation recommencing with deposition of radiolarian-rich sediments characterized by the $D$. davidii Assemblage (lower Jamieson Formation of Pattillo and Nicholls, 1990). In the Carnarvon Basin, the zone is associated with the Windalia Radiolarite (Hocking et al., 1987, p. 151).

The middle to early Aptian Odontochitina operculata Zone occupies the upper part of lithologic Unit V, which was predominantly claystone with rhodochrosite and radiolarite; samples were collected from medium to dark gray and black claystone horizons. All samples were dominated by microplankton (Table 1). The associations were characterized by major abundances of taxa not encountered in these numbers in more proximal depositional locations (Batiacasphaera and Leptodinium). An apparent inverse relationship exists between the numbers of Spiniferites and the microplankton to spore/pollen ratio, which may reflect an 


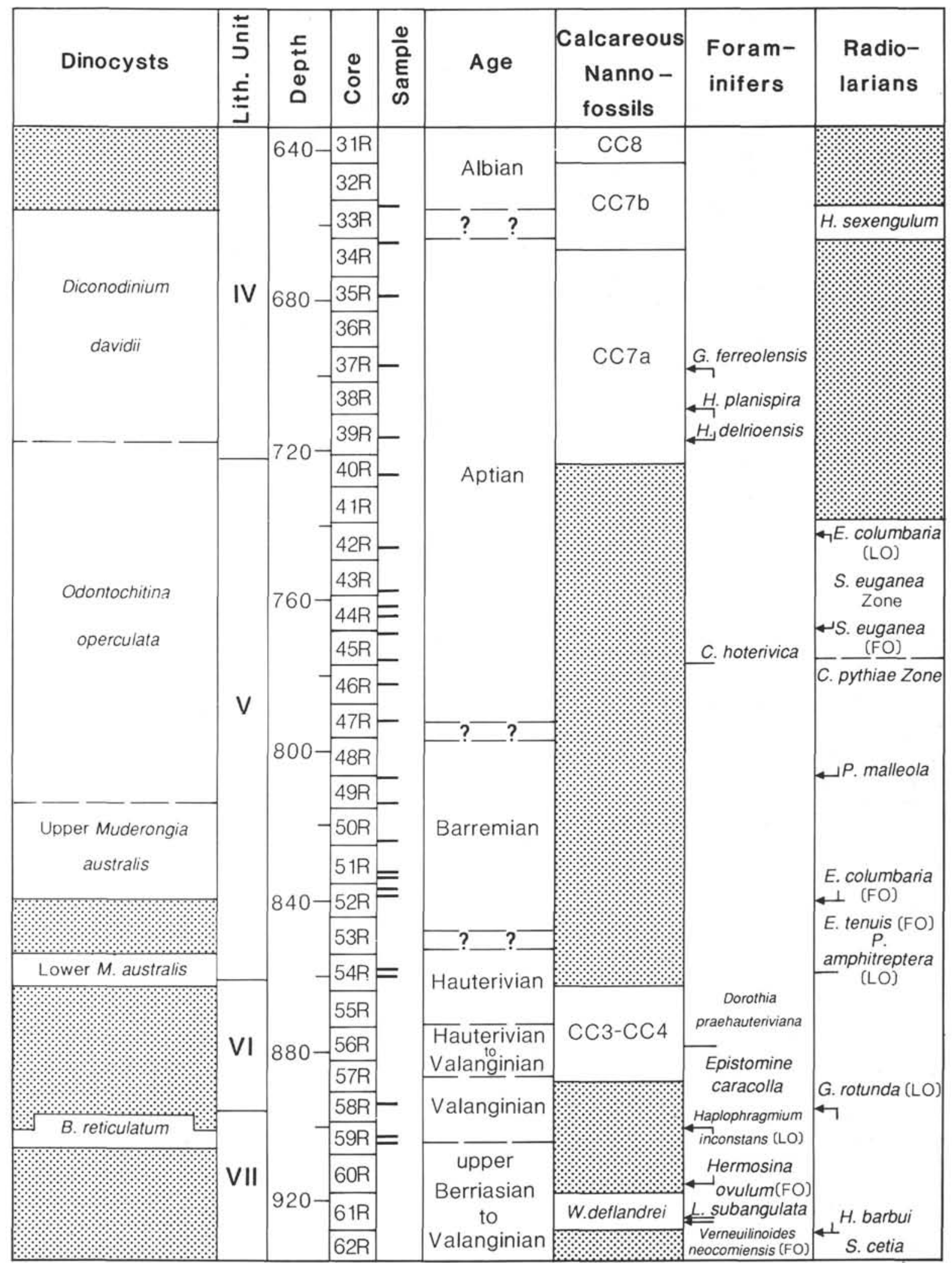

Figure 2. Early Cretaceous biostratigraphy at Site 765. 
Table 1. Palynological summary.

\begin{tabular}{|c|c|c|c|c|c|}
\hline \multirow{2}{*}{$\begin{array}{l}\text { Core, section, } \\
\text { interval }(\mathrm{cm})\end{array}$} & \multirow{2}{*}{$\begin{array}{l}\text { Palynomorph } \\
\text { yield }\end{array}$} & \multicolumn{3}{|c|}{ Counts } & \multirow[b]{2}{*}{ Zone } \\
\hline & & (1) & (2) & (3) & \\
\hline $123-765 \mathrm{C}-33 \mathrm{R}-1,38-40$ & Very low & $3: 1$ & 38 & $11 \%$ & Diconodinium davidii \\
\hline $34 \mathrm{R}-1,130-132$ & Low & $1: 5$ & 37 & $2.5 \%$ & Diconodinium davidii \\
\hline a35R-CC & Moderate & $4: 1$ & 48 & $4.5 \%$ & Diconodinium davidii \\
\hline 37R-CC & Ext. low & $1: 1$ & 10 & $2 \%$ & Indeterminate \\
\hline $39 \mathrm{R}-\mathrm{CCl}$ & Ext. low & $2: 1$ & 9 & - & Diconodinium davidii \\
\hline a $40 \mathrm{R}-4,138-140$ & Moderate & 19:1 & 37 & $1.5 \%$ & Odontochitina operculata \\
\hline $42 \mathrm{R}-2,117-119$ & Low & $3: 1$ & 21 & $19 \%$ & Odontochitina operculata \\
\hline $43 \mathrm{R}-1,111-112$ & Low & $19: 1$ & 25 & $5 \%$ & Odontochitina operculata \\
\hline 43R-CC & Low & $4: 1$ & 35 & $7 \%$ & Odontochitina operculata \\
\hline $44 \mathrm{R}-1,100-102$ & Moderate & $49: 1$ & 42 & $1 \%$ & Odontochitina operculata \\
\hline $44 \mathrm{R}-\mathrm{CC}$ & Low & $9: 1$ & 20 & $1 \%$ & Odontochitina operculata \\
\hline a $45 \mathrm{R}-1,12-14$ & Moderate & 19:1 & 31 & $3 \%$ & Odontochitina operculata \\
\hline $45 \mathrm{R}-\mathrm{CC}$ & Very low & $16: 1$ & 31 & $1 \%$ & Odontochitina operculata \\
\hline $47 R-3,39-40$ & Low & $99: 1$ & 18 & $0.5 \%$ & Odontochitina operculata \\
\hline $49 \mathrm{R}-1,125-126$ & Low & $4: 1$ & 73 & $10.5 \%$ & Odontochitina operculata \\
\hline 49R-CC & Very low & $9: 1$ & 32 & $2.5 \%$ & Odontochitina operculata \\
\hline as0R-CC & Low & $99: 1$ & 28 & $0.5 \%$ & Muderongia australis \\
\hline a $51 R-5,106-107$ & Low & $19: 1$ & 39 & $2 \%$ & Muderongia australis \\
\hline $51 \mathrm{R}-\mathrm{CC}$ & Moderate & $99: 1$ & 23 & $0.5 \%$ & Muderongia australis \\
\hline $52 \mathrm{R}-1,150-151$ & Moderate & $6: 1$ & 37 & $1 \%$ & Muderongia australis \\
\hline $52 \mathrm{R}-2,36-40$ & Low & $9: 1$ & 43 & $7.5 \%$ & Muderongia australis \\
\hline a $54 \mathrm{R}-4,49-50$ & Low & $99: 1$ & 35 & $\operatorname{Tr}$ & Lower $M$. australis \\
\hline 54R-CC & Low & $49: 1$ & 18 & - & Lower M. australis \\
\hline 58R-2, 14-19 & Ext. low & NR & 3 & - & Indeterminate \\
\hline $59 R-4,105-112$ & Low & $9: 1$ & 76 & $\operatorname{Tr}$ & Lower Batioladinium reticulatum \\
\hline $123-765 C-59 R-5,8-9$ & Low & $4: 1$ & 47 & $\operatorname{Tr}$ & Batioladinium reticulatum or older \\
\hline
\end{tabular}

a Single species mounts prepared. Counts: (1) microplankton to spores/pollen ratio; (2) microplankton diversity (s.1.); (3) Spiniferites as proportion of microplankton. $\mathrm{NR}=$ not recorded; $\mathrm{Tr}=$ trace.

increase in the number of taxa introduced from more proximal locations by turbidity flow. The 0 . operculata Zone is commonly obscured by a supercondensed section in the Timor Sea region. The zone occurs in the Muderong Shale in the Carnarvon Basin, where it exhibits much higher spore/pollen to microplankton ratios and is associated with substantial vascular plant debris, reflecting more proximal depositional locations.

The Barremian Muderongia australis Zone occupies the lower part of lithologic Unit V (Fig. 2, see also von Rad et al., 1989, Fig. 9). The lithology is predominantly claystone with minor radiolarite; samples were collected from green-gray, medium to dark gray and black claystone intervals. The palynomorph suites were totally dominated by moderately diverse microplankton associations (Table 1). Acmes of Batiacasphaera and Cribroperidinium sp. cf. C. asarotum occurred in the upper part of the zone. The Muderongia australis Zone occurs in the upper part of the lower member of the Darwin Formation (Hughes, 1978) and in the Echuca Shoals Formation (Pattillo and Nicholls, 1990) in the Timor Sea region, as well as the lower part of the Muderong Shale in the Carnarvon Basin.

The Berriasian lower part of the Batioladinium reticulatum Zone was encountered in Cores 123-765C-59R-4 and -59R-5, which are located in the upper part of lithologic Unit VII. The lithology is predominantly brown-red silty claystone, and samples were taken from thin intercalations of dark gray claystone. The palynomorph residues were dominated by diverse microplankton suites, with evidence of Jurassic reworking. Rare specimens of taxa, not known to extend below the middle to late Valanginian Senoniasphaera tabulata Zone (not recorded in Hole 765C), were encountered in the samples. These are considered to represent downhole contamination. The alternative proposition, that the relatively abundant representation from the $B$. reticulatum Zone is reworked, is considered unlikely. The B. reticulatum Zone occurs only rarely in the Timor Sea region, where it was not deposited, has been removed, or is obscured by a supercondensed sequence. This zone has been identified recently in a well in the Arafura Sea. Over much of the Carnarvon Basin, the zone occurs in the upper Barrow Group and exceeds $650 \mathrm{~m}$ in some wells.

\section{CONCLUSIONS}

The Early Cretaceous palynological sequence in Hole $765 \mathrm{C}$ resembles sequences in the coastal margin basins of the Australian Northwest Shelf. The sequence is, in descending order, the late Aptian Diconodinium davidii Zone (Cores 123-765C-33R to $-39 \mathrm{R}$ ), the middle to early Aptian Odontochitina operculata Zone (Cores 123-765C-40R to -49R), the Barremian Muderongia australis Zone (Cores $123-765 \mathrm{C}-50 \mathrm{R}$ to $-54 \mathrm{R}$ ), and the Berriasian lower Batioladinium reticulatum Zone (Core 123-765C-59R). Only a few dinocyst species have not been recorded previously on the Northwest Shelf. The quantitative distribution of taxa in Hole $765 \mathrm{C}$, particularly below the late Aptian, was not encountered in the marginal basins and possibly reflects the extreme distal locus of deposition. The ages assigned to the dinocyst zones by Helby et al. (1987) are essentially supported by dating from other fossil groups (Fig. 2).

\section{ACKNOWLEDGMENTS}

A. McMinn publishes with permission of the Director of the Geological Survey of New South Wales.

\section{REFERENCES}

Backhouse, J., 1988. Late Jurassic and Early Cretaceous palynology of the Perth Basin, Western Australia. Bull. Geol. Surv. West. Aust., 123:1-233.

Helby, R., Morgan, R., and Partridge, A. D., 1987. A palynological zonation of the Australian Mesozoic. In Jell, P. A. (Ed.), Studies in Australian Mesozoic Palynology. Mem. Assoc. Australas. Palaeontol., 4:1-94,

Hocking, R. M., Moors, M. T., and van der Graaff, W.J.E., 1987. The geology of the Carnarvon Basin, Western Australia. Bull. Geol. Surv. West. Aust., No. 133. 
Hughes, R. J., 1978. The geology and mineral occurrences of the Bathurst Island, Melville Island, and Coburg Peninsula, Northern Territory. Bull.Bur. Miner. Resour., Geol. Geophys. (Aust.), 177:1-72.

Ingram, B., and Morgan, R., 1988. The development and status of Mesozoic palynostratigraphy of the North West Shelf, Australia. In Purcell, P. G., and Purcell, R. R. (Eds.), The North West Shelf, Australia. Proc. Pet. Expl. Soc. Aust. Symp., 581-590.

Islam, M. A., 1988. Palynological Age-dating of Seismic Horizons D, E and $\mathrm{F}$ in the Beagle and Dampier Sub-basins. In Purcell, P. G., and Purcell, R. R. (Eds.), The North West Shelf, Australia. Proc. Pet. Expl. Soc. Aust Symp., 599-604.

Lentin, J. K., and Williams, G. L., 1989. Fossil dinoflagellates: index to genera and species. Am. Assoc. Stratigr. Palynol. Contrib. Ser., 20:1473.

Pattillo, J., and Nicholls, P. J., 1990. A tectonostratigraphic framework for the Vulcan Graben, Timor Sea region. APEA J., 30:27-51.

von Rad, U., Thurow, J., Haq, B. U., Gradstein, F., Ludden, J., and ODP Leg 122/123 Shipboard Scientific Parties, 1989. Triassic to Cenozoic evolution of the NW Australian continental margin and the birth of the Indian Ocean (preliminary results of ODP Legs 122 and 123). Geol. Rundsch., 78:1189-1210.

Wiseman, J. F., and Williams, A. J., 1974. Palynological investigation of samples from Sites 259, 261, and 263, Leg 27 Deep Sea Drilling Project. In Veevers, J. J., Heirtzler, J. R., et al., Init. Repts. DSDP, 27: Washington (U.S. Govt. Printing Office), 915-924.

Date of initial receipt: 10 July 1990

Date of acceptance: 15 May 1991

Ms 123B-121

\section{APPENDIX}

Species List

Achomosphaera? neptuni (Eisenack, 1954) Davey and Williams, 1966

Adnatosphaeridium tutulosum (Cookson and Eisenack, 1960) Morgan, 1980

Aldorfia deflandrei (Clark and Verdier, 1967) Stover and Evitt, 1978

Angustidinium acribes (Davey and Verdier, 1971) Goodman and Evitt, 1981

Aprobolocysta galeata Backhouse, 1987

Apteodinium granulatum Eisenack, 1958

Apteodinium maculatum Eisenack and Cookson, 1960

Batiacasphaera imperfecta Stover and Helby, 1987

Batiacasphaera scrobiculata (Deflandre and Cookson, 1955) Burger, 1980

Batiacasphaera subtilis Stover and Helby, 1987

Batioladinium jaegeri (Alberti, 1961) Brideaux, 1975

Batioladinium longicornutum (Alberti, 1961) Brideaux, 1975

Batioladinium micropodum (Eisenack and Cookson, 1960) Brideaux, 1975

Batioladinium reticulatum Stover and Helby, 1987

Belodinium dysculum Cookson and Eisenack, 1960

Broomea simplex Cookson and Eisenack, 1958

Callaiosphaeridium asymmetricum Davey and Williams, 1966

Canningia reticulata Cookson and Eisenack, 1960 emend. Helby, 1987

Canninginopsis intermedia Morgan, 1980

Canninginopsis tabulata (Davey and Verdier, 1974) Duxbury, 1977

Carpodinium granulatum Cookson and Eisenack, 1962

Cassiculosphaeridia magna Davey, 1974

Cassiculosphaeridia reticulata Davey, 1969

Cernicysta helbyi (Morgan, 1980) Stover and Helby, 1987

Chichaouadinium boydii (Morgan, 1980) Bujak and Davies, 1983

Chlamydophorella nyei Cookson and Eisenack, 1958

Chytroeisphaeridia chytroeides (Sarjeant, 1962) Downie and Sarjeant, 1965 emend. Davey, 1979

Circulodinium colliveri (Cookson and Eisenack, 1960) Helby, 1987

Circulodinium deflandrei Alberti, 1961

Circulodinium hirtellum Alberti, 1961

Cleistosphaeridium ancoriferum (Cookson and Eisenack, 1960) Davey et al., 1966 emend, Cookson and Eisenack, 1968

Codoniella campanulata (Cookson and Eisenack, 1960) Downie and Sarjeant, 1965

Cometodinium? whitei (Deflandre and Courteville, 1939) Stover and Evitt, 1978

Coronifera oceanica Cookson and Eisenack, 1958

Cribroperidinium aparsium Stover and Helby, 1987

Cribroperidinium asarotum Stevens, 1987
Cribroperidinium edwardsii (Cookson and Eisenack, 1958) Davey, 1969

Cribroperidinium leedervillense Backhouse, 1988

Cribroperidinium muderongense (Cookson and Eisenack, 1958) Davey, 1969

Dapsilidinium warrenii (Habib, 1976) Lentin and Williams, 1981

Diconodinium davidii Morgan, 1975

Diconodinium pusillum Singh, 1971

Dingodinium cerviculum Cookson and Eisenack, 1958

Dingodinium jurassicum Cookson and Eisenack, 1958

Dissimulidinium lobispinosum May et al., 1987

Dollidinium sinuosum (Cookson and Eisenack, 1960) Helby and Stover, 1987

Egmontodinium torynum (Cookson and Eisenack, 1960) Davey, 1979 Elytrocysta circulata (Clarke and Verdier, 1967) Stover and Helby, 1987 Epelidosphaeridia colligata (Morgan, 1980) Lentin and Williams, 1985 Epitricysta vinckensis Stover and Helby, 1987

Exiguisphaera phragma Duxbury, 1979

Exochosphaeridium arnace Davey and Verdier, 1973

Exochosphaeridium phragmites Davey et al., 1966

Exochosphaeridium robustum Backhouse, 1988

Eyrea nebulosa Cookson and Eisenack, 1971

Fibradinium variculum Stover and Helby, 1987

Florentinia mantellii (Davey and Williams, 1966) Davey and Verdier, 1973

Fromea amphora Cookson and Eisenack, 1958

Fromea monilifera Backhouse, 1987

Gardodinium attenuatum Stover and Helby, 1987

Gardodinium lowii Backhouse, 1987

Gonyaulacysta helicoidea (Eisenack and Cookson, 1960) Sarjeant, 1960

Gonyaulacysta jurassica (Deflandre, 1938) Norris and Sarjeant, 1965

Hapsocysta peridictya (Eisenack and Cookson, 1960) Davey, 1979

Herendeenia postprojecta Stover and Helby, 1987

Heslertonia striata (Cookson and Eisenack, 1960) Norvick, 1976

Hystrichosphaeridium pachydermum Cookson and Eisenack, 1960

Hystrichosphaeridium petilum Gitmez, 1970

Impagidinium phlyctaena Stover and Helby, 1987

Kaiwaradinium scrutillinum Backhouse, 1987

Kallosphaeridium norvickii Burger, 1980

Kiokansium polypes (Cookson and Eisenack, 1962) Below, 1982

Kleithriasphaeridium fasciatum (Davey and Williams, 1966) Davey, 1974

Kleithriasphaeridium simplicispinum (Davey and Williams, 1966) Davey, 1974

Leptodinium asymmetricum Morgan, 1980

Leptodinium eumorphum (Cookson and Eisenack, 1960) Sarjeant in Davey et al., 1969

Leptodinium pinnosum Davey, 1988

Leptodinium simplex Burger, 1980

Leptodinium tunellum Stover and Helby, 1987

Meiourogonyaulax maculata Backhouse, 1988

Meiourogonyaulax stoveri Millioud, 1969

Meiourogonyaulax sp. B - Helby et al., 1987

Muderongia australis Helby, 1987

Muderongia macwhaei Cookson and Eisenack, 1958

Muderongia tetracantha (Gocht, 1957) Alberti, 1961

Occisucysta tenuiceras (Eisenack, 1958) Below, 1981

Odontochitina operculata (Wetzel, 1933) Deflandre and Cookson, 1955

Oligosphaeridium anthophorum (Cookson and Eisenack, 1958) Davey, 1969

Oligosphaeridium asterigerum (Gocht, 1959) Davey and Williams, 1966

Oligosphaeridium complex (White, 1842) Davey and Williams, 1966

Oligosphaeridium poculum Jain, 1977

Oligosphaeridium pulcherrimum (Deflandre and Cookson, 1955) Davey and Williams, 1966

Palaeoperidinium cretaceum Pocock, 1962

Phoberocysta neocomica (Gocht, 1957) Millioud, 1969 emend. Helby, 1987

Platycystidia eisenackii (Mehrotra and Sarjeant, 1984) Backhouse, 1988

Prolixosphaeridium inequiornatum Stover and Helby, 1987

Prolixosphaeridium parvispinum (Deflandre, 1937) Davey et al., 1969

Protoellipsodinium densispinum Morgan, 1980

Pseudoceratium turneri Cookson and Eisenack, 1958

Pterospermella aureolata (Cookson and Eisenack, 1958) Eisenack, 1972

Pterospermella australiensis (Deflandre and Cookson, 1955) Eisenack and Cramer, 1973

Pyxidiella tumida Stover and Helby, 1987 


\section{R. HELBY, A. MCMINN}

Pyxidinopsis challengerensis Habib, 1976

Rhombodella paucispina (Alberti, 1961) Duxbury, 1980

Rigaudella aemula (Deflandre, 1938) Below, 1982

Schizocystia laevigata Cookson and Eisenack, 1962

Scriniodinium attadalense (Cookson and Eisenack, 1958) Eisenack, 1967

Scriniodinium? campanula Gocht, 1959

Senoniasphaera ptomatis Helby, May and Partridge in Helby, 1987

Senoniasphaera tabulata Backhouse and Helby in Helby, 1987

Sirmiodinium grossii Alberti, 1961

Systematophora areolata Klement, 1960
Systematophora palmula Davey, 1982

Tanyosphaeridium boletus Davey, 1974

Trichodinium castanea (Deflandre, 1935) Clarke and Verdier, 1967

Tubotuberella vlamingii Backhouse, 1987

Wallodinium krutzschii (Alberti, 1961) Habib, 1972

Wallodinium luna (Cookson and Eisenack, 1960) Lentin and Williams, 1973

Yalkalpodinium scutum Morgan, 1980

Full details of the citations can be found in Lentin and Williams (1989). 


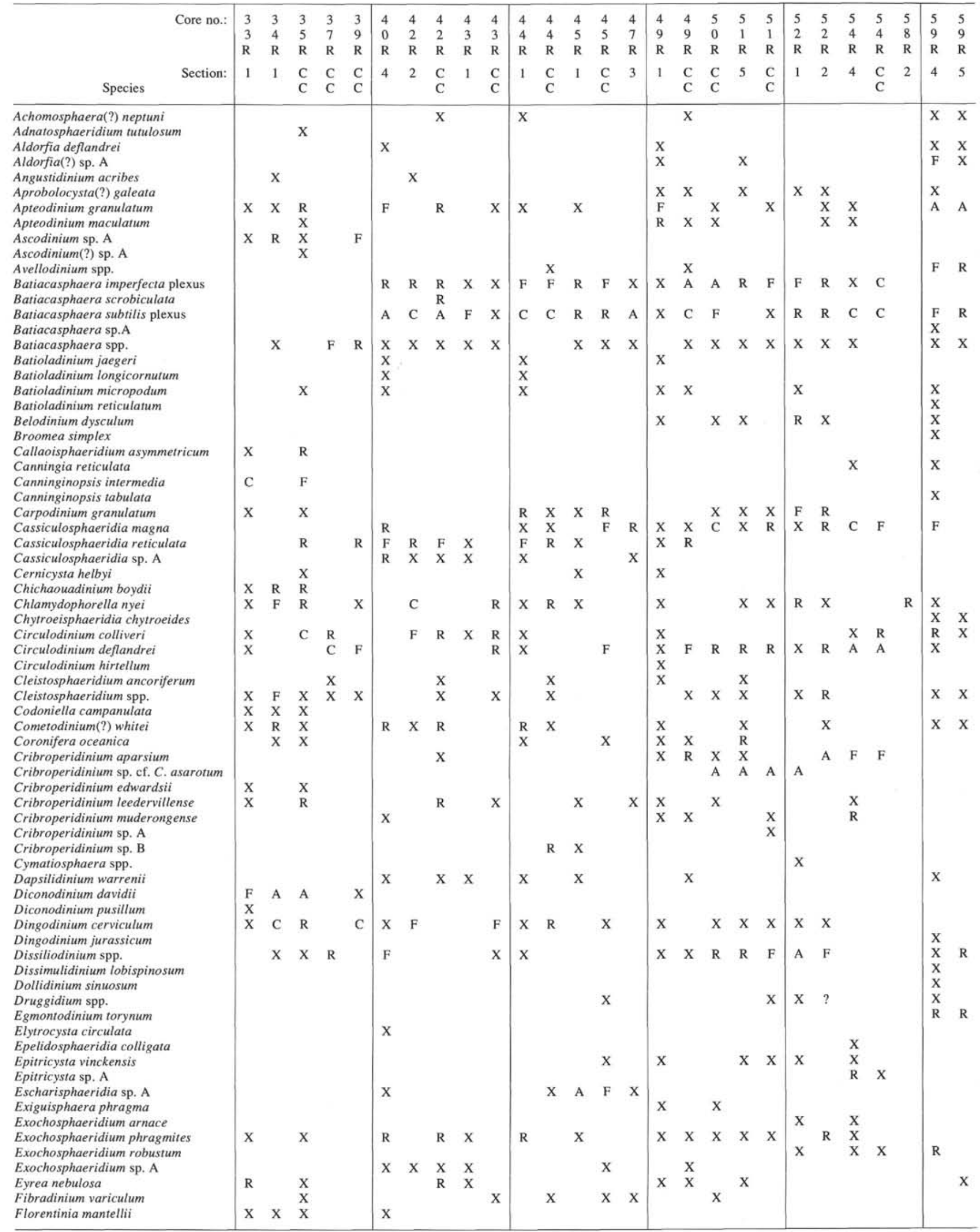


Table 2 (continued).

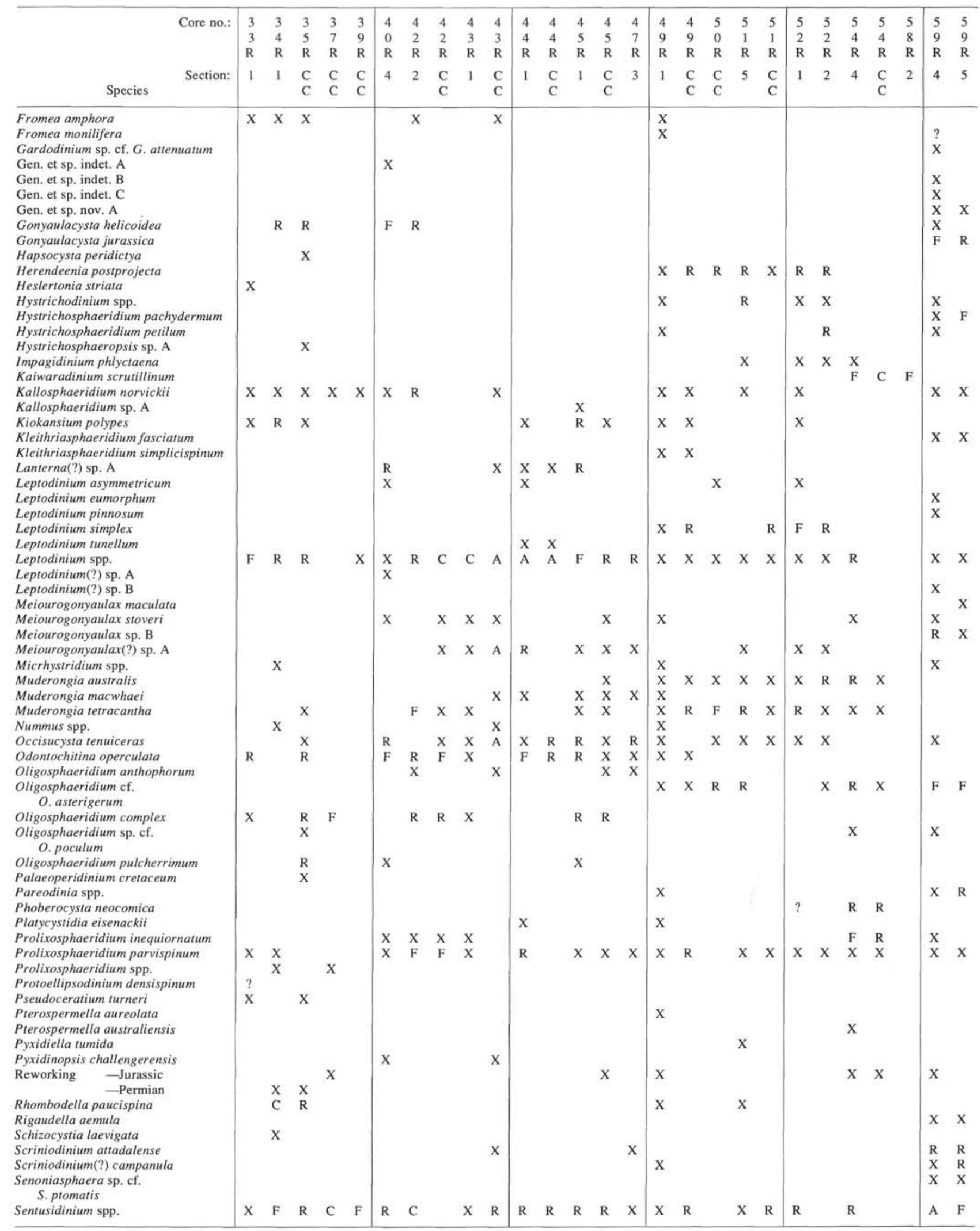


Table 2 (continued).

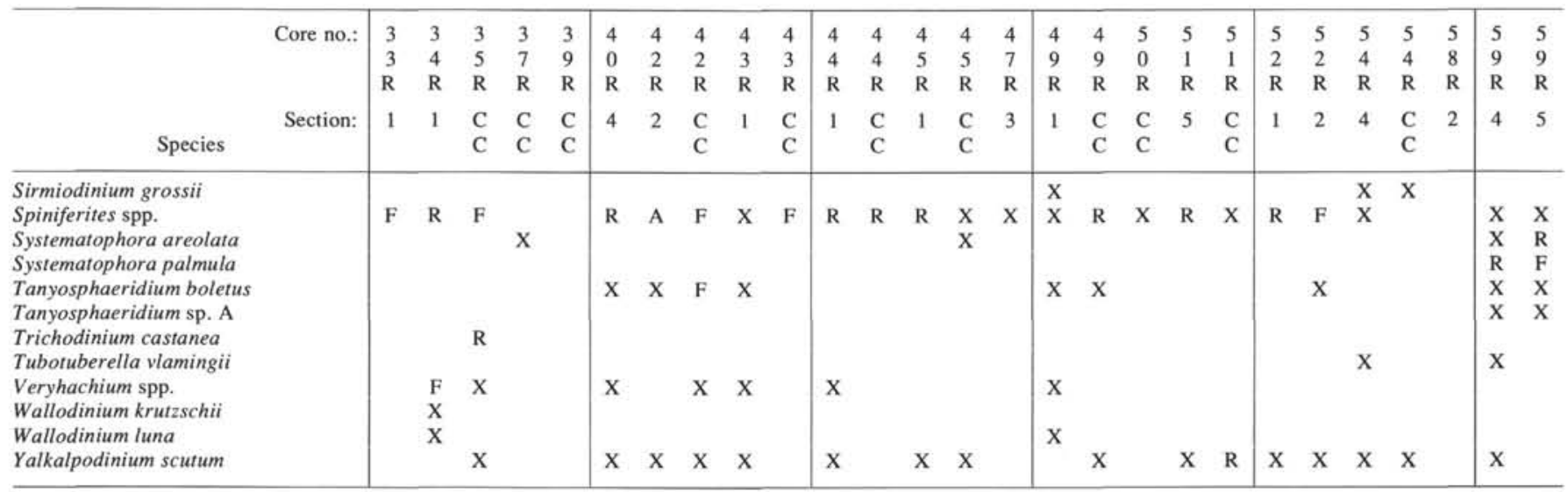

$\mathrm{A}=>30 \% ; \mathrm{C}=>10 \%-<30 \% ; \mathrm{F}=>3.5 \%-<10 \% ; \mathrm{R}=>1 \%-<3.5 \% ; \mathrm{X}=<1 \%$ 

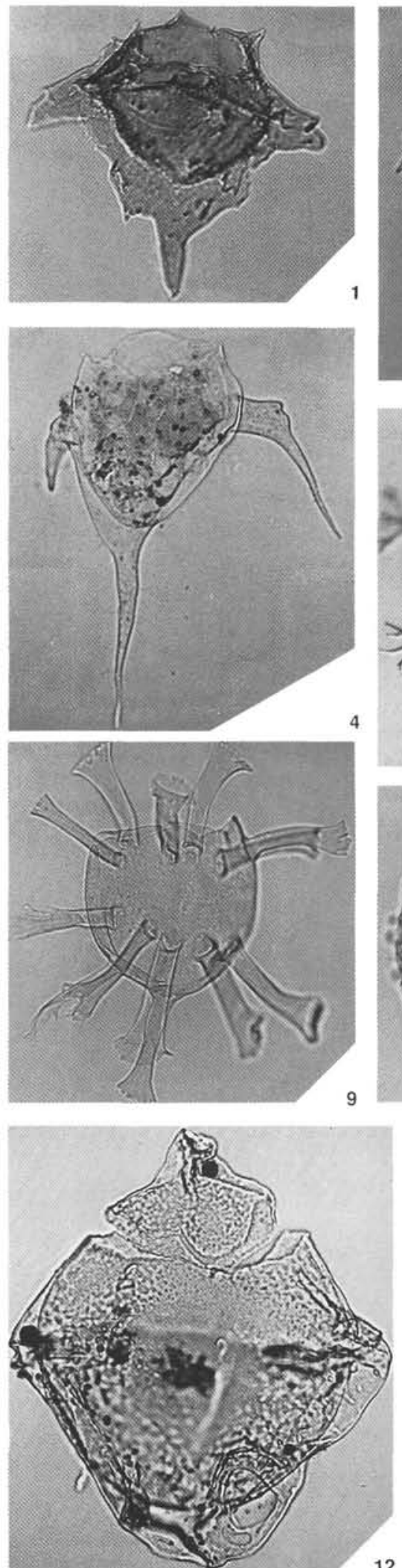

12
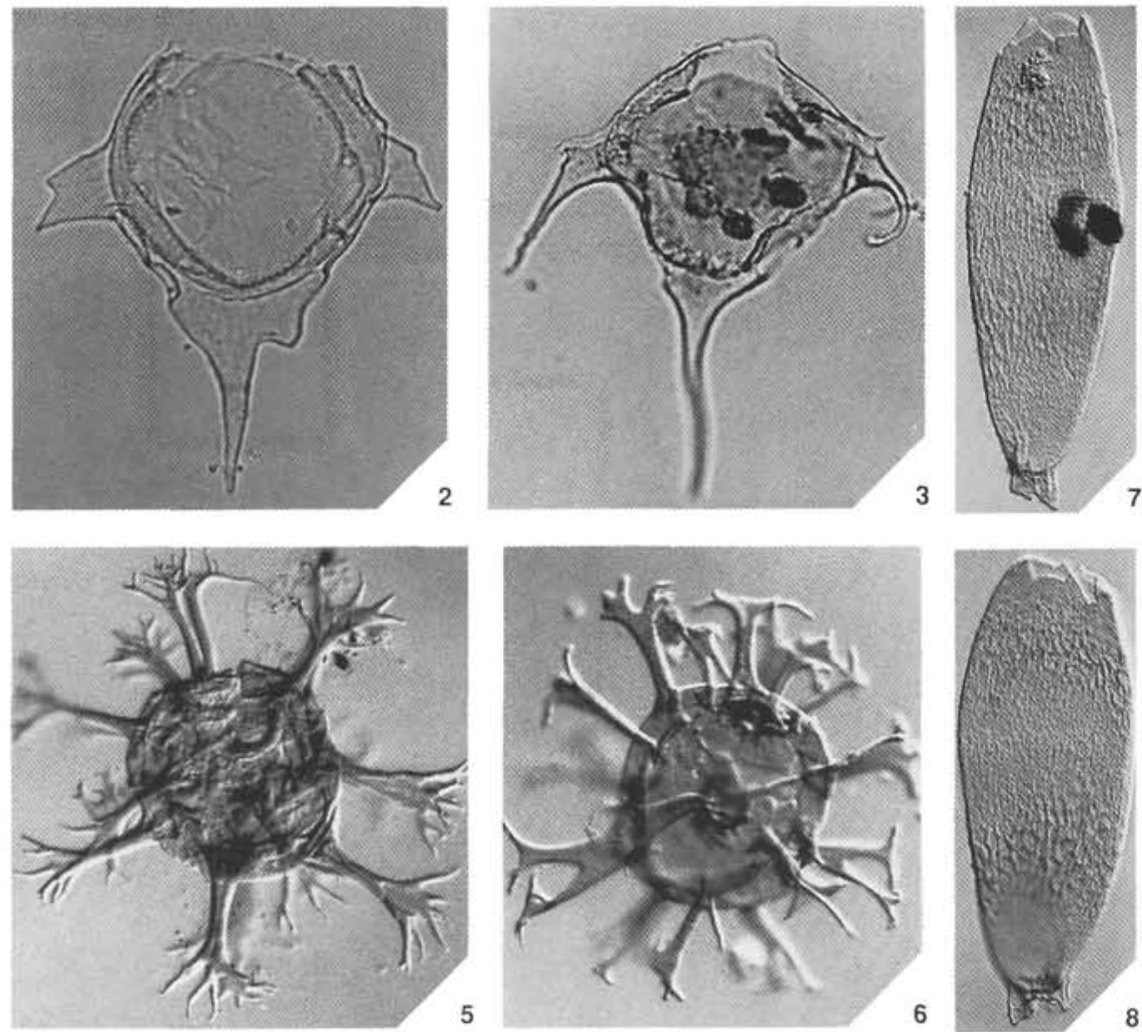

8
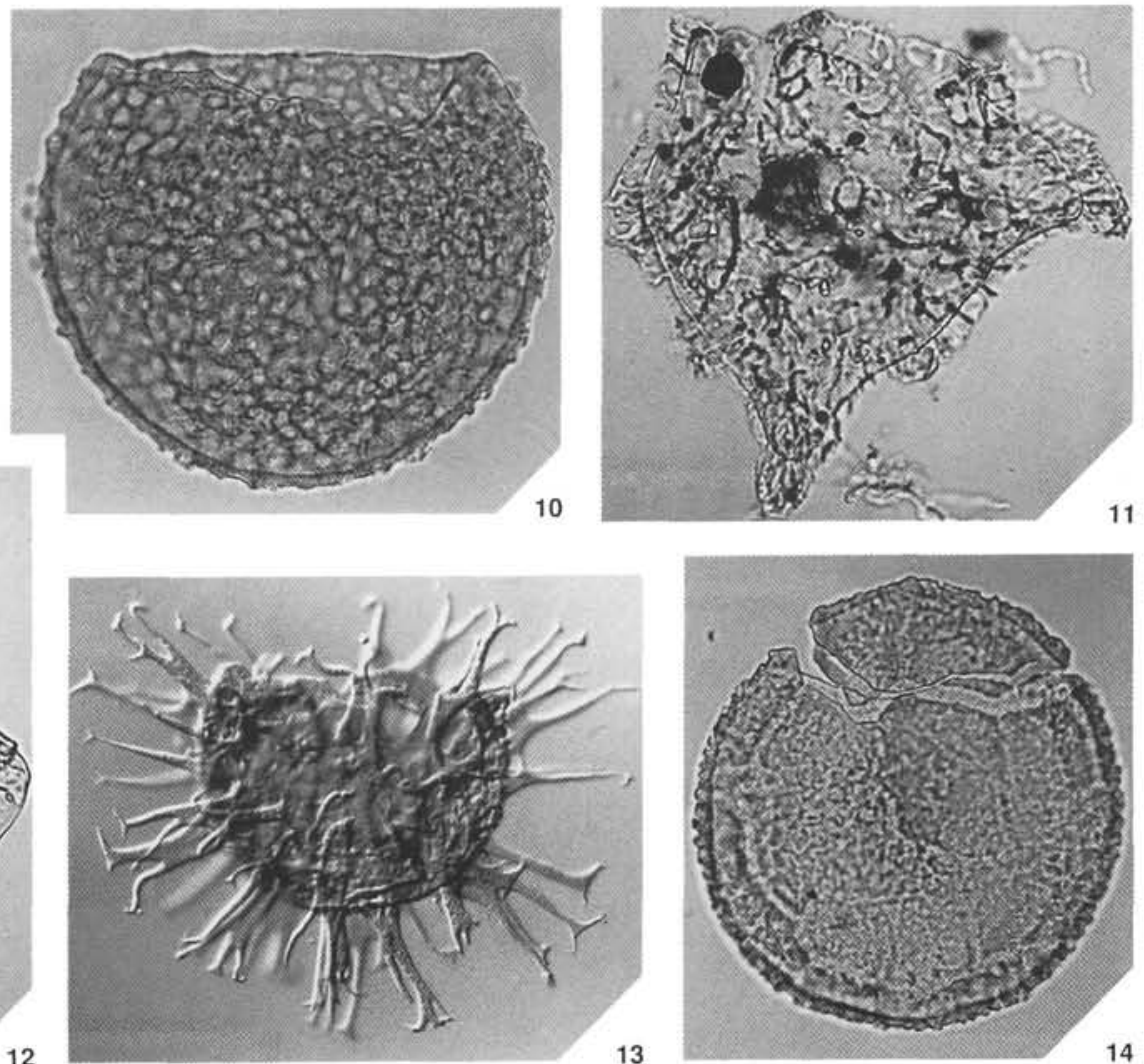

Plate 1. (all x500) 1. Phoberocysta neocomica (Core 123-765C-54R-4 SSM6). 2. Muderongia australis (Core 123-765C-51R-5 SSM12). 3. Muderongia sp. cf. $M$. tetracantha (Core 123-765C-35R-CC SSM35). 4. Muderongia tetracantha (Core 123-765C-50R-CC SSM11). 5. Oligosphaeridium asterigerum (Core 123-765C-59R-4 SSM26). 6. Systematophora palmula (Core 123-765C-59R-4 SSM20). 7. Gen. et sp. nov. A (Core 123-765C-59R-4 SSM5). 8. Gen. et sp. nov. A (Core 123-765C-59R-4 SSM6). 9. Kaiwaradinium scrutillinum (Core 123-765C-54R-4 SSM1). 10. Cassiculosphaeridia magna (Core 123-765C-54R-4 SSM8). 11. Pseudoceratium turneri (Core 123-765C-35R-CC SSM8). 12. Yalkalpodinum scutum (Core 123-765C-35R-CC SSM10). 13. Systematophora areolata (Core 123-765C-59R-4 SSM15). 14. Meiourogonyaulax? sp. A (Core 123-765C-40R4 SSM1). 

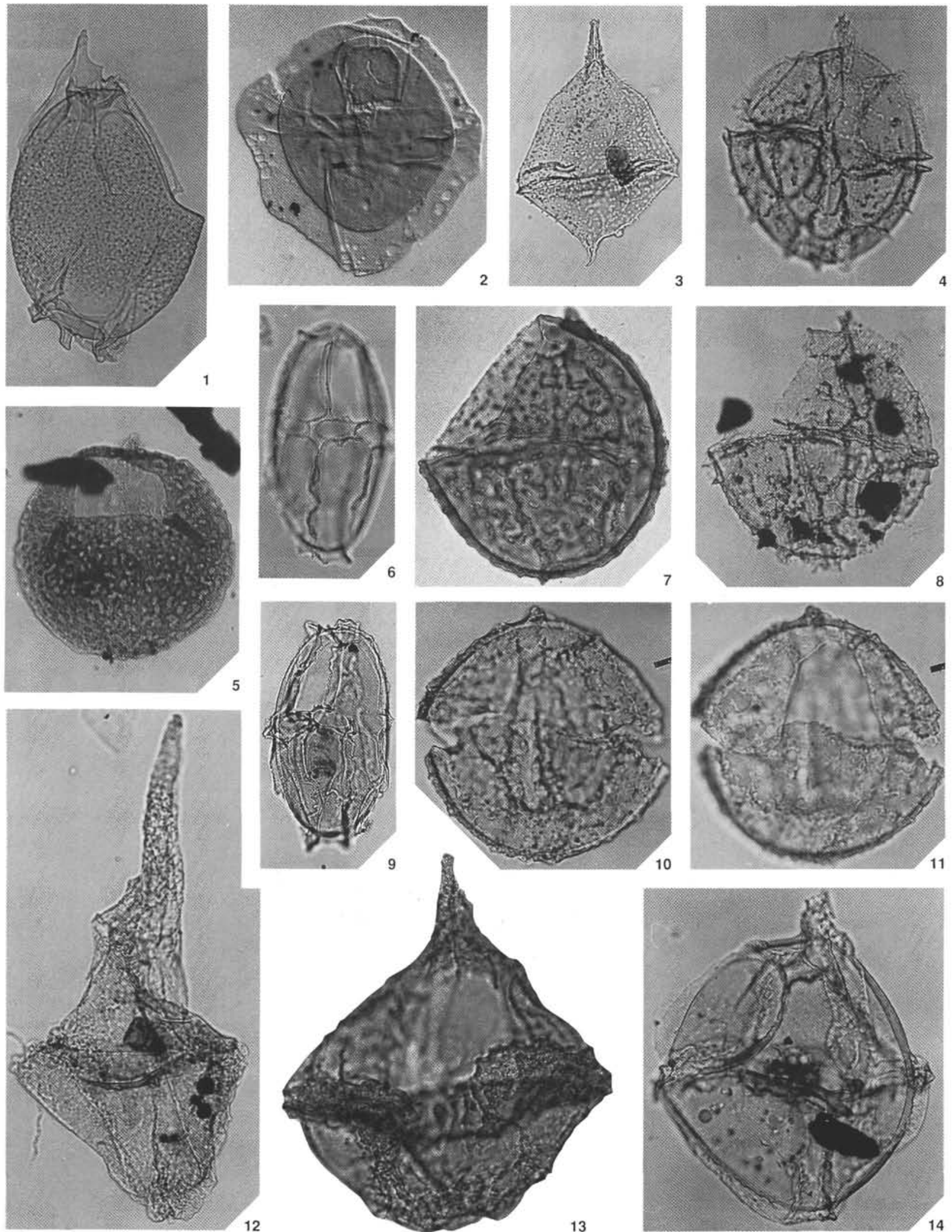

Plate 2. (all x500) 1. Herendeenia postprojecta (Core 123-765C-51R-5 SSM1). 2. Scriniodinium attadalense (Core 123-765C-59R-4 SSM31). 3. Diconodinium davidii (Core 123-765C-35R-CC SSM2). 4. Occisucysta tenuiceras (Core 123-765C-40R-4 SSM2). 5. Aldorfia? sp. A (Core 123-765C-59R-4 2/922 199). 6. Carpodinium granulatum (Core 123-765C-51R-5 SSM4). 7. Cribroperidinium sp. cf. C. asarotum (Core 123-765C-54R-4 SSM25). 8. Occisucysta tenuiceras (Core 123-765C-40R-4 SSM2). 9. Carpodinium granulatum (Core 123-765C-50R-CC SSM9). 10,11. Cribroperidinium? sp. cf. C. asarotum (Core 123-765C-51R-5 SSM9). 12. Cribroperidinium sp. cf. C. leedervillense (Core 123-765C-35R-CC SSM25). 13. Cribroperidinium sp. A (Core 123-765C-54R-4 SSM27). 14. Cribroperidium sp. B (Core 123-765C-45R-1 SSM15). 

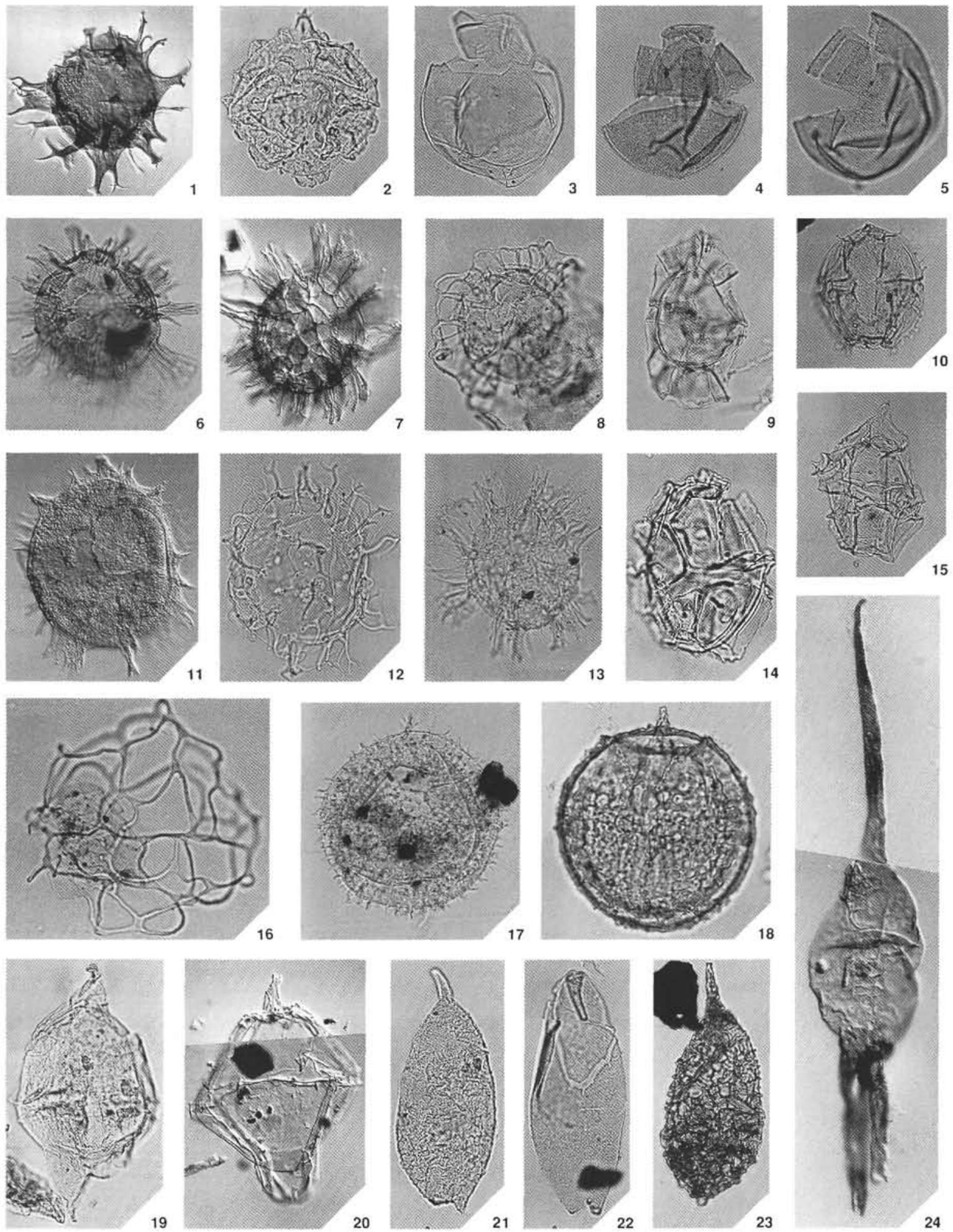

Plate 3. (all x500) 1. Achomosphaera? neptuni (Core 123-765C-59R-4 SSM36). 2. Leptodinium? sp. (Core 123-765C-40R-4 SSM7). 3. Ascodinium? sp. A (Core 123-765C-35R-CC SSM33). 4. Dissiliodinium sp. A (Core 123-765C-40R-4 SSM19). 5. Dissiliodinium sp. A (Core 123-765C-4OR-4 SSM20). 6. Kleithriasphaeridium fasciatum (Core 123-765C-59R-SSM34). 7. Kleithriaspbaeridium fasciatum (Core 123-765C-59R-4 1/1100 110). 8. Adnatosphaeridium tutulosum (Core 123-765C-35R-CC SSM31). 9. Hystrichosphaeropsis sp. A (Core 123-765C-35R-CC SSM22). 10. Leptodinium? sp. (Core 123-765C-59R-4/956 040). 11. Exochosphaeridium arnace (Core 123-765C-54R SSM25). 12. Avellodinium sp. A (Core 123765C-51R-5 SSM6). 13. Exochosphaeridium sp. A. (Core 123-765C-40R-4 SSM18). 14. Impagidinium phlyctaena (Core 123-765C-51R-4 SSM4). 15. Gonyaulacysta sp. cf. G. helicoidea (Core 123-765C-40R-4 SSM17). 16. Hapsocysta perdictya (Core 123-765C-35R-CC SSM30). 17. Trinchodinium castanea (Core 123-765C-35R-CC SSM24). 18. Cribroperidinium sp. cf. C asarotum (Core 123-765C-50R-CC SSM4), 19. Ascodinium sp. A (Core 123765C-35R-CC 1/1160 180). 20. Tubotuberella vlamingii (Core 123-765C-59R-4 SSM33). 21. Batioladinium micropodum (Core 123-765C-35R-CC SSM14). 22. Batioladinium micropodum (Core 123-765C-40R-4 SSM30). 23. Batioladinium reticulatum (Core 123-765C-59R-4 1/1092 218). 24. Broomea simplex - reworked (Core 123-765C-59R-4 SSM28). 

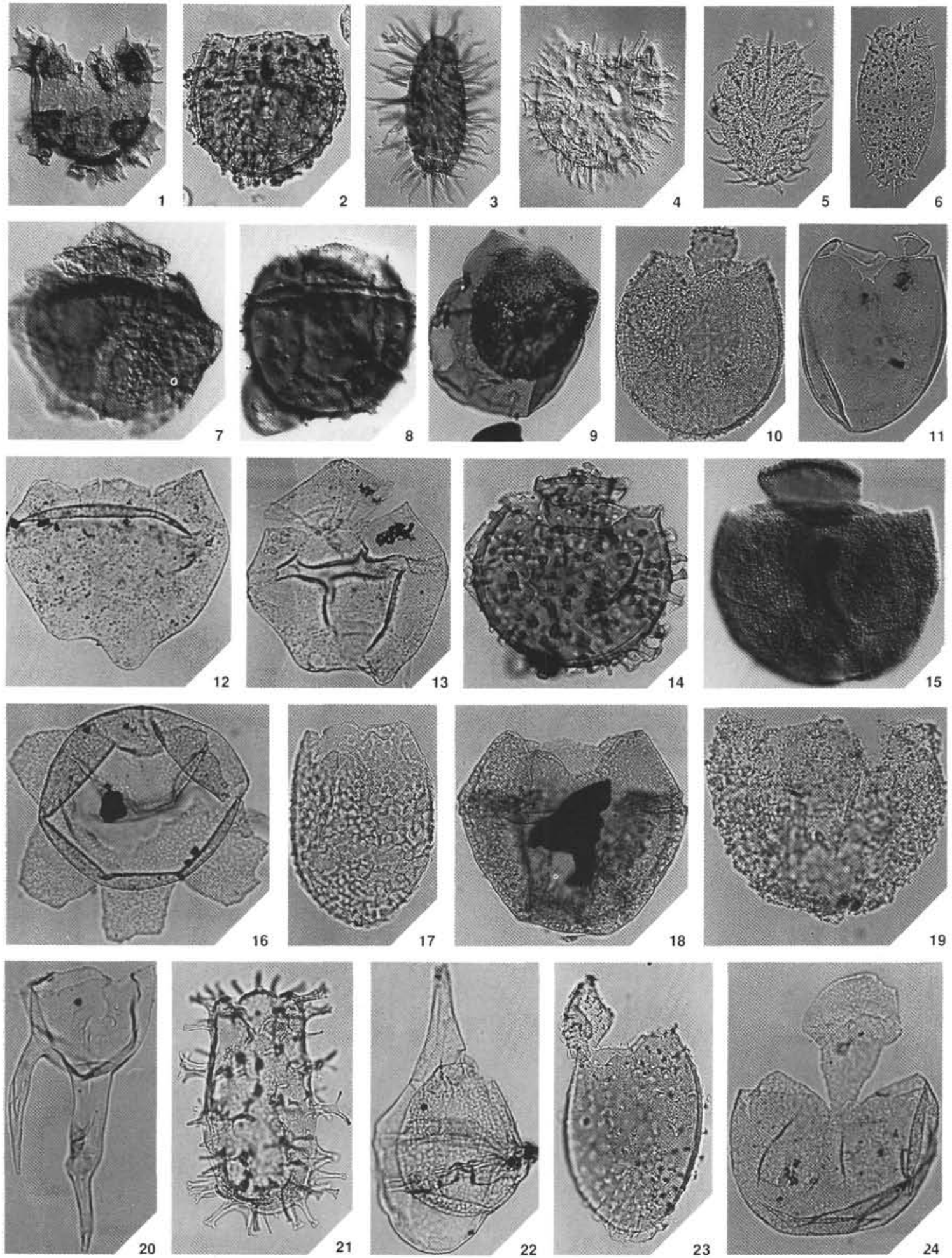

Plate 4. (all x500) 1. Oligosphaeridium sp. cf. O. poculum (Core 123-765C-59R-4 SSM24). 2. Meiourogonyaulax? sp. A (Core 123-765C-50R-CC SSM5). 3. Tanyosphaeridium sp. A (Core 123-765C-59R-4 SSM16). 4. Epelidosphaeridia colligata (Core 123-765C-54R SS13). 5. Prolixosphaeridium parvispinum (Core 123-765C-40R-4 SSM46). 6. Prolixosphaeridium inequiornatum (Core 123-765C-54R-5 SSM11). 7. Senoniasphaera sp. cf. S. ptomatis (Core 123-765C-59R-4 SSM23). 8. Meiourogonyaulax sp. B (Core 123-765C-59R-4 SSM10). 9. Dingodinium jurassicum (Core 123-765C-59R-4 2/911 130). 10. Batiacasphaera sp. (Core 123-765C-40R-4 SSM46). 11. Batiacasphaera? sp. (Core 123-765C-4OR-4 SSM51). 12. Canninginopsis intermedia (Core 123-765C-35R-CC SSM6). 13. Canninginopsis intermedia (Core 123-765C-35R-CC SSM6). 14. Meiourogonyaulax? sp. A (Core 123-765C-45R-1 SSM10). 15. Batiacasphaera sp. A-imperfecta plexus (Core 123-765C-59R-4 1/995 210). 16. Escharisphaeridia sp. A (Core 123-765C-45R-1 SSM4). 17. Batiacasphaera sp.-imperfecta plexus (Core 123-765C-51R-5 SSM6). 18. Meiourogonyaulax stoveri (Core 123-765C-40R-1 SSM33). 19. Genet sp. indet. A (Core 123-765C-40R-4 SSM37). 20. Odontochitina operculata (Core 123-765C-40R-4 SSM31). 21. Egmontodinium torynum (Core 123-765C-59R-4 SSM12). 22. Dingodinium cerviculum (Core 123-765C-35R-CC SSM17). 23. Batiacasphaera? sp. imperfecta plexus (Core 123-765C-45R-1 SSM8). 24. Kallosphaeridium sp. A (Core 123-765C-45R-1 SSM14). 

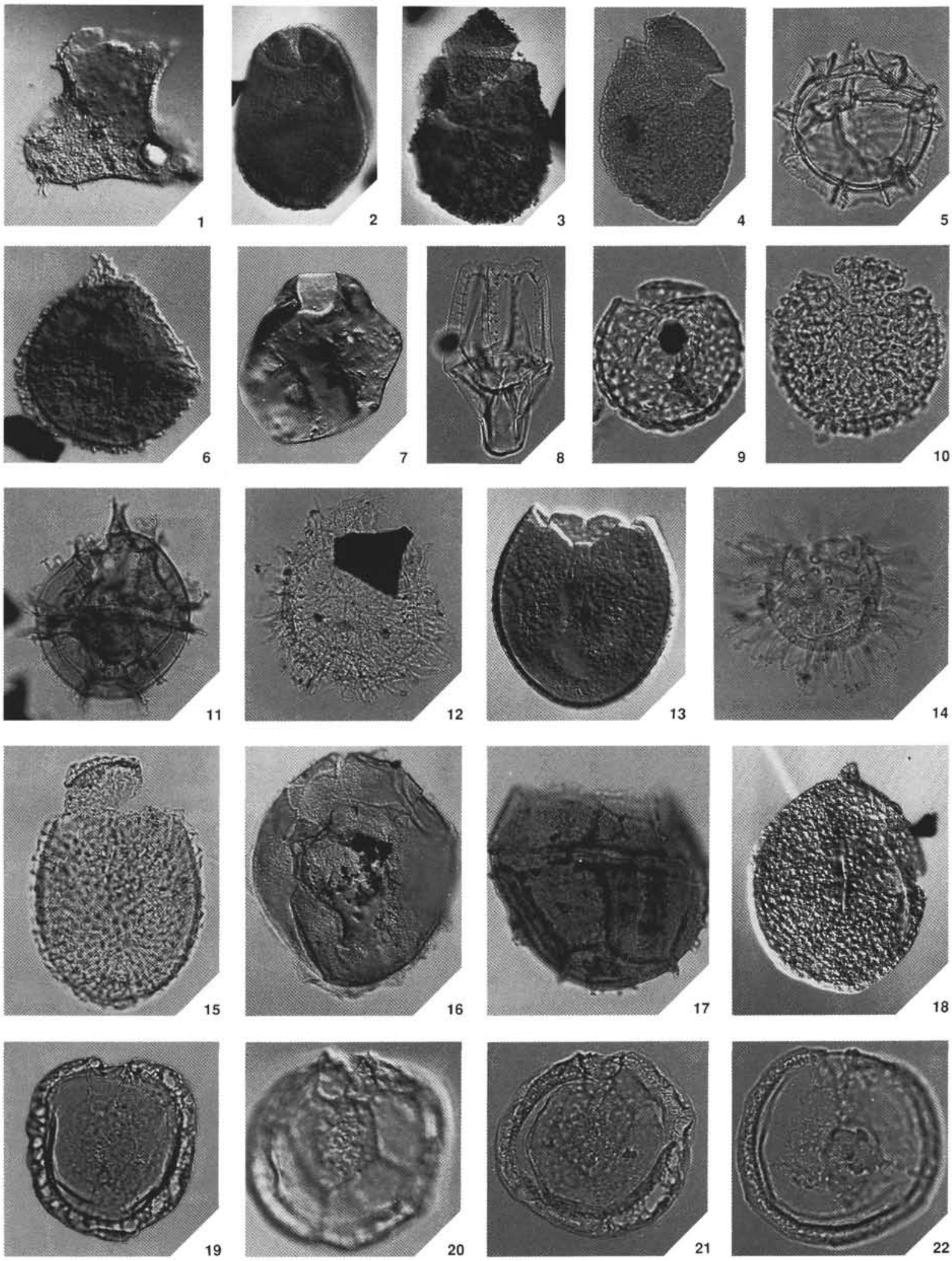

Plate 5. (all x750) 1. Dissimulidinium lobispinosum (Core 123-765C-59R-4 SSM17). 2. Gen. et sp. indet. B (Core 123-765C-59R-4 1/1084 190). 3. Aprobolocysta? galeata (Core 123-765C-59R-42/1030 150), 4. Aprobolocysta? galeata (Core 123-765C-59R-4 2/955 225). 5. Leptodinium sp. (Core 123-76SC-35R-CC SSM15). 6. Aldorfia deflandrei (Core 123-765C-59R-4 SSM20). 7. Dollidinium sinuosum (Core 123-765C-59R-4 SSM41). 8. Belodinium dysculum (Core 123-765C-51R-6 SSM3). 9. Cassiculosphaeridia sp. A (Core 123-765C-40R-4 SSM50). 10. Batiacasphaera sp.-imperfecta plexus (Core 123-765C-40R-4 SSM48). 11. Spiniferites? sp A (Core 123-765C-59R-4 1/1113 040). 12. Cometodinium? whitei (Core 123-765C-40R-4 SSM28). 13. Batiacasphaera sp.-subtilis plexus (Core 123-765C54R-4 SSM13). 14. Dapsilidinium warrenii (Core 123-765C-40R-4 SSM44). 15. Batiacasphaera sp.-imperfecta plexus (Core 123-765C-50R-CC SSM5). 16. Gen. et sp. indet. C(Core 123-765C-59R-4 1/900 145). 17. Meiourogonyaulax sp. B (Core 123-765C-59R-4 1090210). 18. Aldorfia? sp. A (Core 123-765C-59R-4 SSM29). 19-22. Epitricysta sp. A (all Core 123-765C-54R-4 SSM19). 